\title{
Self, Ideal and Salvation: A Comparative Study of Jane Austen's Elizabeth and Cao Xueqin's Lin Daiyu
}

\author{
Xiuhua Zhuang \\ English Department, Zhenjiang Watercraft College of PLA, Zhenjiang, China \\ Email: tracyzxh@163.com \\ Juan Chen \\ The Third Kindergarten of Taiyuan Railway, Qingdao, China \\ Email: 412767069@qq.com
}

\begin{abstract}
Elizabeth and Lin Daiyu, the two typical enchanting heroines, though created by different authors, set in the different countries and cultural backgrounds, bear a significantly close resemblance to one another in their personality: they all possess the ideals that they should get the true love and have a happy life. However, there are some distinct differences between their ideals and ways of realizing them.
\end{abstract}

Index Terms —Elizabeth, Lin Daiyu, heroines, comparative study

\section{INTRODUCTION}

Elizabeth and Lin Daiyu were created in different backgrounds of 18 th century. One was at the time of the Enlightenment in Britain while the other was in the Ching Dynasty, the declining period of feudalism in China. The two heroines strived for their ideals, which appeared rather progressive at their time.

Elizabeth was the second daughter in the Bennet family, a middle-class family of Longbourn, near London. She received a good education at home and lived an uneventful life with her parents and other four sisters. Lin Daiyu also spent her early childhood in a well-to-do family. She could read and write, too. But unfortunately, due to the early death of her mother, she had to move to her grandmother's residence and lived there without parental love.

However, both of them possessed their own ideals for love and happiness, though shown in different ways.

\section{COMPARISON BETWEEN ElIZABETH \& LiN DAIYU}

\section{A. Different Characters of Two Fair Ladies}

1. Elizabeth: independent and take the initiative in her own hands

Elizabeth was the protagonist of Pride and Prejudice and one of the most well-known feminine characters in English literature. She had charming personality and was adored by the audience greatly. Her honesty, virtue, and lively wit enabled her to rise above the other girls in the family. She was intelligent and playful, unafraid to let her opinions known by others, and at the same time polite and good-mannered. She was always the first to recognize the reality of a situation, and was able to understand people very well. Unlike her elder sister Jane, she did not see the absolute best in everyone and every situation.

She refused marriage proposals two times. One is that she turned down her cousin Collins' court, because she did not like him at all. In her eyes, Collins was a vulgar man and was not the type she wanted. Therefore, she was not persuaded into marrying him. The other is that she rejected Mr. Darcy, a handsome and extremely wealthy aristocrat, because of his arrogance. Afterwards, the misunderstanding was cleared up between Elizabeth and Darcy and they fell into love. But Darcy's haughty aunt Lady Catherine did not approve of this marriage. Elizabeth did not yield and finally got the true love she longed for. All this shows that Elizabeth had her own judgments, own thought and own understanding about love and marriage.

2. Lin Daiyu: bashful, whiny but versatile and straightforward

Lin Daiyu was the protagonist of Dream of the Red Mansion. She was one of the fair ladies with poetic temperament in Daguan Garden of Jia family. Although she was whiny now and then, she was not calculating. On the contrary, the young lady was sincere and serious to others, especially to Zijuan and Xiangling. For example, once Xinagling wanted to learn how to write poems, Xue Baochai, who was considered kind and graceful, refused to teach her. Then Xiangling turned to consult Daiyu. Daiyu taught her very patiently and borrowed her some great collections of poems.

Lin was a sentimental lady. For instance, she had a special feeling towards flowers. Seeing flowers fading, she could not help her sorrow and wrapped the fallen petals with a hop-pocket, and then put them in the earth for fear that the 
petals would drift into river or get trampled. She also associated her own fate with the flower, which was in full bloom only for a short time before withering. What a pessimistic girl she was. However, she had strong self-esteem and was afraid of ridicule from others and always cautious in doing everything.

But deeply in her heart there was a passion for love, which could be easily found in the way she treated Jia Baoyu-the direct heir of Jia family. Although she was sensitive, whiny, unsocial and sharp-tongued to others on the surface, she was frank, naive and emotional. In her mind the true love calls for wholehearted devotion between the two. Therefore she cared about Baoyu's attitude toward her, because Baoyu was her entire hope. Although there were some defects in her characters, they could not cover up her charm. To this straightforward and helpless lady, she had to use some ways to stop her from being hurt. When her hope was strangled by harsh reality, she died soon, which was a straight way to express her resistance.

\section{B. Two Ladies' Rosy Ideals about Love and Marriage}

Elizabeth and Lin Daiyu had some similarities in resisting the unfairness imposed on them from the society, the freedom of love and marriage. They were both unwilling to yield to fate. But they had some differences in their views of marriage.

1. Elizabeth's ego and ideal

Marrying a rich aristocrat bachelor was the dream of young ladies at Elizabethan time. Just as it goes: "It is a truth universally acknowledged that a single man in possession of a good fortune must be in want of a wife". Therefore all the young ladies grasped any opportunity to show themselves in front of the rich noble bachelors in order to attract their eyes. However, Elizabeth did not follow the trend blindly. She considered that a marriage based on property, money, and status was unwise. A marriage should not simply depend on material things; instead, it should seek the foundation in mutual understanding and appreciation.

Elizabeth refused Darcy at first because she did not like his arrogance. What's more, some misunderstandings led to their estrangement. And they held strong prejudice against each other initially, which resulted in the discrepancy between them. But with time going on, the arrogance disappeared and the prejudice was cleared up, Elizabeth and Darcy fell in love and got married in the end.

2. Lin Daiyu's ideal of love

In contrast, Lin Daiyu, the Chinese classical tragic heroine, lived in the 18th century during the reign of Emperor Qian-long of the Ching Dynasty, the last feudal dynasty in China. At that time, women were supposed to be inferior to men in every respect. Striving for freedom of love from women was remarked ridiculous. However, some enlightened concepts that advocate equality among love and marriage evoked Lin Daiyu's consciousness of progressive thought. Finally, this inflexible lady struggled for her ideal till she died.

Daiyu and Baoyu grew up together since their adolescence. As time went on, they understood each other better and the two had much in common. Daiyu loved Bayou deeply; meanwhile she expected she was special in his heart. In her opinion, love was pure without impurity; love was unique without being unfaithful; love was earnest without falseness. And the most important was that the lovers should love each other heart and soul. Only in this way could the love be eternal. But the freedom of love could not be accepted in feudal society. Her fancy ideal faded away gradually, which was inevitable under that circumstance.

\section{Differences in Self-salvation of Two Heroines}

Both in Britain and in China of 18th century, the social status of men and women were not equal. In Britain, the laws deprived women of the right of inheritance if there were male descendants in the family. And the right of governing property belonged to their husbands once they got married. In China, women were faced with worsened situation: they should adhere to "three obediences", i.e. one should obey her father when at home and her husband after getting married and her son after the husband died. Their marriage was decided by their parents, so young ladies had no right to choose their spouses on their own. Therefore, the two heroines' bears much resemblance in their rebelling consciousness. Still, there are some differences between their self-consciousness and self-salvation.

1. Elizabeth's rebelling consciousness and self-salvation

According to Elizabeth, a marriage should base on the material guarantee and love. The two factors were indispensable. Meanwhile, the future husband should be chosen by herself instead of others. She refused two suitors resolutely. The former was her cousin Collins, although he possessed considerable property and was considered an ideal son-in-law by her mother. The latter was the aristocrat Mr. Darcy, who was accepted by Elizabeth until all the misunderstanding melted between them. Elizabeth's unflinchingness and wit made her gain happiness in the end.

i) Middle-class family background and good education

Elizabeth was a fair lady who belonged to the middle-class. Her family was in Longbourn, which was a small town and never disturbed by class conflicts. When Elizabeth was young, she received good education at home and read plenty of books. Therefore, she could absorb lots of enlightened thoughts. And she was adored and influenced greatly by her father, another wise person in the Bennet family.

The uneventful life and good education fostered her elegant, quick-witted, intelligent characters. She was not like her elder sister Jane who was so delicate and easy to believe in everyone, nor was she like her shallow and ignorant younger sisters. When she met some tough problems, she would keep cool-headed and thought by herself. The intelligent and 
quick-witted fair lady could recognize the essence of the matter. This was her distinctive difference from others.

In her mind, a marriage should be equal between men and women. Marriage could not be ideal without true love. She adhered to such principle all the time. And she maintained independence and kept the initiative in her own hands. At the critical moment, she said "no" bravely, using her own ways to achieve her ideal. All this showed that she had strong self-consciousness.

ii) Strive for equality; uphold self-esteem

In Elizabeth's mind, women should gain the respect from men especially in marriage. She expected the ideal marriage with true love, which was beyond pride and prejudice. When Darcy's aunt Lady Catherine stopped her from marrying Darcy, her reaction revealed her distinct concept of love: "You are not entitled to know mine. Nor will such behavior as this ever induce me to be explicit." "And if I am that choice, why may not I accept him?" "In marrying your nephew, I should not consider myself as quitting that sphere. He is a gentleman; I am a gentleman's daughter; so far we are equal." The response showed Elizabeth's earnest love to Darcy, and her unwavering resolution broke Catherine's vicious plan. Meanwhile, her self-esteem was well upheld.

Lady Catherine's supercilious attitude did not made Elizabeth withdraw. On the contrary, it provided a great chance for Darcy to propose to Elizabeth for the second time.

2. Lin Daiyu's rebelling consciousness

Lin Daiyu is a typical tragic heroine in Chinese literature. She was naive, pure and not hypocritical. She loved Baoyu earnestly, and even expected to marry Baoyu someday. Although she eventually failed in marrying him, her high self-dignity impresses the audience deeply.

i) Feudal landlord family and good education

Lin Daiyu was a feudal officer's daughter; she received a good education at home when she was young. As the only child in Lin's family, she was the apple of her parents' eyes. Her parents treated her like a boy without much discipline. And she was not influenced by some orthodox ideas. Therefore, she had a carefree childhood. But unfortunately, her parents died early. She had to move to her grandmother's residence, which was a big and brilliant feudal landlord mansion. It provided her an extremely luxurious life, and there she and Baoyu had many chances to communicate with each other. Daiyu's naive, elegant, rebellious and witty characters attracted Baoyu deeply. They found that they had much in common so they gradually fell in love. Their love based on the common ideal which resisted the traditional ideas and pursued the freedom of true love. They became soul mates who held the same ethical and aesthetic code. Although they quarreled over trifles, it could not stop them loving each other.

ii) Dream of love; uphold self-esteem

Lin Daiyu was a progressive lady who pursued pure love and expected to escape from traditional dogmas' bandage. She sought love perseveringly and cherished it carefully. She held the secret love dear to herself, and often said one thing but meant another. She was sensitive, emotional and sometimes even considered hard to deal with by the servants. Though literate and intelligent, some traditional ideas lingered in her mind, which hindered her in speaking out herself. She hoped her grandmother, the hostess of Jia family, stand out to help her to attain her dream of marring Baoyu. Unfortunately, her grandmother did not do so although she was fond of her. When the last hope was gone, this delicate lady had to yield to destiny. Her fragile physical condition deteriorated quickly and died soon. In some degree Daiyu used her life to protest against the unfair treatment of the patriarchal feudal society.

Daiyu's high sense of self-consciousness was very impressive. During that time, Daiyu's action was not approved, even considered ridiculous by others, but to those women who had the same consciousness was an amazing deed. However, her actions were different from Elizabeth's. Generally speaking, she was passive to accept the arrangement of fate while Elizabeth pursued what she wanted in a more active way. Therefore, different family backgrounds, different rebelling consciousness led to their different fates -- one was happy while the other was tragic.

\section{Different Fates, Different Endings}

\section{Elizabeth: All shall be well, and Jack has his Jill}

Love is magic. It always makes fun of lovers. Later, Elizabeth through many ways realized that Darcy was not a haughty and impolite man and gradually, changed her attitude to him. Meanwhile Darcy also altered his views to Elizabeth. So the pride and prejudice disappeared between them. Darcy proposed to Elizabeth for a second time, Elizabeth accepted it agreeably.

Indeed, Elizabeth and Darcy was a couple who were admired by others. They overcame lots of obstacles and achieved their ideal. Elizabeth was a fortunate and happy lady. Her persistence, independence and bravery led her to true love.

2. Lin Daiyu: pretty woman suffers unhappy end

Lin Daiyu was a clever, versatile and emotional lady. But such a delicate lady could not free herself from tragic fate. As Chinese saying goes: "pretty women ofen suffer unhappy fates." She struggled for her ideal all her life. However, women were not allowed to resist in the feudal society. To Daiyu, she did not have the right to choose her life partner and nobody gave a hand to her. The old tradition was like the ocean and she was a sailing boat against the wind in the ocean, and was finally turned over by the rough sea. She was too weak to change her destiny. Praiseworthy, she preferred to die rather than compromise with antis on love of freedom. She and Baoyu were separated by the patriarchal system. This was not only their personal tragedy, but also the tragedy of that time. 


\section{CONCLUSION}

Elizabeth and Lin Daiyu, the two charming heroines in Western literature and Chinese literature, were both created in a mingled social background in the same century, when a new social order as well as a new intellectual order were going to be set up, which evoked the profound consideration of self, ideals and salvation among some progressive minds. The two ladies hold fast to true love and marriage. However, the different social environment, different family backgrounds and different characters of the two heroines resulted in different ends. The former, gained the true love and had a happy ending, while the latter, vanished and died miserably in despair.

Elizabeth succeeded in winning her love, not only because of her firm, wise and independent characters, but also owning to the enlightened social environment which was different from that of China. This British lady was luckier than the Chinese one, because she had the chance to choose what she wanted. Fortunately her future was controlled by herself. Yet, Daiyu was unlucky. Although she resisted the unfair treatment to her, she could not change anything in the end. She had no ability to change her fate, even had no chance to choose her happiness. She was just the victim of feudal system of Qing Dynasty. Daiyu's tragic fate reflected the injustice imposed on women in the ancient China.

As to their similarities and differences, there will be a lot of work to do. This article may shed some light on future research in this concern.

\section{REFERENCES}

[1] Cao Xueqin and Gao E. (2000). Dream of the Red Mansion. Changsha Yuelin Press.

[2] Jane Austen. (2002). Pride and prejudice. Hohhot Inner Mongolia People's Press.

[3] Long Zhijian. (2005). Interpreting the Characters of A Dream of Red Mansion. Journal of Xiangnan University.

[4] Wang Jingjing. (2006). The Same and Difference of Traditional Marriage Value Between China and Western Countries Reflected in Dream of the Red Chamber and Pride and Prejudice. Journal of Hubei Adult Educational Institute.

[5] Wang Yan. (2006). Self, Ideal and Tragedy: A Comparative Study of Shakespeare's Hamlet and Cao Xueqin's Jia Baoyu. Proceedings of the 2006 International Symposium on Applied Linguistics and Language Teaching. The Hong Kong Polytechnic University Press.

[6] Zhou Ruchang. (2005). Analysis of Dream of Red Mansion by Zhou Ruchang. Guilin: Li River Press.

Xiuhua Zhuang was born in Shandong, China in 1973. She received her M.A. degree in Applied Linguistics from Nanjing University, China in 2005.

She is currently an associate professor in the English Department, Zhenjiang Watercraft College of PLA, Zhenjiang, China. Her research interests include Second Language Acquisition and Foreign Language Teaching.

Juan Chen was born in Shanxi, China in 1984. She is currently a teacher in the Third Kindergarten of Taiyuan Railway, Qingdao, China. Her research interest mainly focuses on the British and American literature. 